Rengki Afria dan Mailani Muadzimah: Variasi Fonologi dan Leksikal Dialek Merangin...

\title{
VARIASI FONOLOGI DAN LEKSIKAL DIALEK MERANGIN DI DESA BUNGOTANJUNG, KAMPUNGLIMO, DAN SUNGAIJERING KECAMATAN PANGKALANJAMBU
}

\author{
Phonology and Lexical Variations of Merangin Dialek in Bungotanjung, Kampunglimo, and \\ Sungaijering Villages, Pangkalanjambu District
}

\author{
Rengki Afria dan Mailani Muadzimah Lijawahirinisa \\ Universitas Jambi \\ Mendalo Indah, Jambi, Indonesia \\ Pos-el: rengkiafria@gmail.com; mailanimuadimah@gmail.com
}

Naskah masuk: 7 Mei 2020, disetujui; 6 Juni 2020, revisi akhir: 20 Juni 2020

\begin{abstract}
Abstrak
Penelitian ini bertujuan untuk mendeskripsikan variasi fonologi dan leksikal dialek Merangin di Desa Bungotanjung, Kampunglimo, dan Sungaijering (TP) Kecamatan Pangkalanjambu (DP). Penelitian ini perlu dilakukan untuk mendeskripsikan situasi kebahasaan di DP berdasarkan penghitungan dialektometri. Metode penelitian menggunakan metode deskriptif kuantitatifkualitatif. Pengumpulan data dilakukan melalui metode cakap, simak, rekam, dan catat. Sumber data berasal dari bahasa Melayu dialek Merangin. Data berupa 200 kosakata Swadesh. Metode analisis data adalah metode padan dan metode dialektometri. Hasil perbandingan titik pengamatan ditemukan variasi fonologi didapatkan $1 \%$ (2 varian) pada TP1-TP2, 2\% (4 varian) pada TP2-TP3, dan 2,5\% (5 varian ) pada TP3-TP1. Sementara, variasi leksikal didapatkan 22 varian atau $11 \%$ pada TP1-TP2, 28 varian atau $14 \%$ pada TP2-TP3, dan 28 varian atau $14 \%$ pada TP3-TP1. Hasil variasi fonologi dan leksikal tersebut menunjukkan status kebahasaan tidak ada perbedaan. Hal tersebut dipengaruhi oleh faktor pertahanan identitas bahasa/dialek, prestise pemakaian bahasa/dialek, faktor kekeluargaan, faktor budaya dan faktor sosial. Oleh karena itu, penelitian ini telah mengidentifikasi bahwa isolek Pangkalanjambu merupakan bagian dari bahasa Melayu, dialek Merangin.
\end{abstract}

Kata Kunci: dialektologi, dialektometri, variasi, fonologi, leksikal.

\begin{abstract}
This study aims to describe the phonological and lexical variations of the Merangin dialect in the villages of Bungotanjung, Kampunglimo, and Sungaijering (TP), Pangkalanjambu District (DP). This research needs to be done to describe the linguistic situation in DP based on dialectometric calculations. The research method uses descriptive quantitative-qualitative methods. Data collection using a method of proficient, consider, and record. The data source is Malay language in Merangin dialect. Data in the form of 200 Swadesh vocabulary's. Data analysis is matching and dialectometry method. The results of comparison of observation points found phonological variation found $1 \%$ (2 variants) on TP1-TP2, $2 \%$ (4 variants) on TP2-TP3, and 2.5\% (5 variants) on TP3-TP1. Meanwhile, lexical variation found 22 variants or $11 \%$ in TP1-TP2, 28 variants or $14 \%$ in TP2-TP3, and 28 variants or 14\% in TP3-TP1. The results of phonological and lexical variations show that there is no difference in linguistic status. This is influenced by language/dialect identity defense factors, prestige of language/dialect usage, family factors, cultural factors and social factors. Therefore, this study has identified that the Pangkalanjambu isolect is part of the Malay language, Merangin dialect.
\end{abstract}

Keywords: dialectology, dialectometri, variation, phonolgy, lexical.

\section{PENDAHULUAN}

Di dunia modern saat ini, keberadaan bahasa daerah mulai sulit diketahui, terlebih yang berada di desa-desa yang jauh. Kondisi masyarakat yang identik dengan sesuatu yang berbau modern dan baru, termasuk bahasa, menjadi pemicu untuk dilakukannya riset atau penelitian terhadap bahasa, khususnya pada dialek bahasa tersebut. Sementara itu, Indonesia adalah tanah yang 
Rengki Afria dan Mailani Muadzimah: Variasi Fonologi dan Leksikal Dialek Merangin...

luas dengan beragam bahasa, beragam dialek, dan beragam logat pula. Untuk itu, peneliti menggagas mengenai variasi dialek secara leksikal dan fonologi, khususnya dialek dalam bahasa Melayu.

Bahasa adalah alat komunikasi yang digunakan manusia, selain untuk berkomunikasi, bahasa juga merupakan sarana untuk berinteraksi dalam lingkungan sosial. Melalui bahasa, manusia dapat saling terhubung satu sama lain. Ditinjau dari konsep tersebut, diketahui bahwasanya bahasa erat dengan masyarakat, karena masyarakat adalah pengguna bahasa. Masyarakat pengguna bahasa tentu menggunakan bahasa daerahnya untuk berkomunikasi dalam lingkungan bahasanya. Bahasa yang digunakan oleh penutur dari suatu daerah disebut bahasa daerah. Bahasa daerah yang ada di Indonesia yang teridentifikasi sebanyak 718 dari 2.560 daerah pengamatan (Badan Bahasa, 2020). Provinsi Jambi oleh Badan Bahasa (2020) terdapat tujuh bahasa, salah satunya adalah bahasa Melayu dialek Merangin. Oleh karena itu, tidak menutup kemungkinan, dialek tersebut mempunyai perbedaan antara tuturan masyarakat yang berada di daerah satu berbeda dengan daerah lain. Perbedaan tersebut dalam dialektologi, dapat berupa fonologi dan leksikal.

Penelitian ini memfokuskan dalam tataran dialektologi di Kabupaten Merangin, pada Kecamatan Pangkalanjambu sebagai daerah pengamatan (DP). Dalam DP tersebut diambil tiga desa sebagai titik pengamatan (TP), yakni Desa Bungotanjung (BT), Desa Kampunglimo (KL), dan Desa Sungaijering (SJ). TP tersebut secara geografis dan administratif terletak berdekatan. Namun, ketiga TP tersebut memiliki perbedaan yang bervariatif dalam menuturkan bahasa/dialeknya. Oleh karena itu, perlu dilakukan penelitian untuk mengetahui variasi fonologi dan leksikal yang dituturkan oleh masyarakat pengguna bahasa/dialek serta menghitung persentase dialektometri untuk menentukan situasi kebahasaan pada DP tersebut. Tolok ukur dipilinnya tiga TP tersebut adalah letak geografisnya, karena semakin dekat daerah tersebut berada dengan daerah lain, maka semakin kecil pula perbedaan dialeknya, dan semakin jauh daerah tersebut dengan daerah lain, maka semakin besar pula perbedaannya. Lebih lanjut, titik pengamatan (TP) dan daerah pengamatan (DP) ini belum pernah diteliti sebelumnya dalam hal penelitian dialektologi. Selain itu, hasil penelitian ini nantinya menjadi sebagai literatur inventarisasi dan dokumentasi bahasa atau dialek daerah yang ada di Provinsi Jambi.

Dialektologi adalah ilmu tentang dialek atau cabang dari linguistik dan mengkaji perbedaan bahasa dengan memperlihatkan perbedaan tersebut secara utuh atau semuanya (Mahsun, 1995:11; Chambers \& Trudgill, 2004; Fernandez, 1993).

Variasi dialek atau bahasa dapat terjadi karena digunakan di tempat tertentu, di waktu tertentu, atau juga pada golongan tertentu. Dengan demikian, dapat disimpulkan bahwasanya dialek membahas mengenai variasi bahasa.

Nadra dan Reniwati (2009:28) menyatakan bahwa variasi leksikal merupakan perbedaan bahasa/dialek yang terjadi pada bidang leksikon. Artinya, ada yang disebut sebagai perbedaan leksikon jika leksikon-leksikon yang digunakan untuk merealisasikan suatu makna dari etimon yang berbeda. Variasi leksikal adalah sebaran leksikon yang berbeda dari dialek yang sama, dan dapat ditelusuri asalusulnya berdasarkan sebaran pengguna bahasanya.

Penelitian sebelumnya sebagai acuan penelitian ini adalah penelitian yang dilakukan oleh Pamolango (2012), Harahap (2014), Afria (2017; 2019), dan Antono et al., (2019). Pamolango (2012) meneliti tentang geografi dialek bahasa Saluan. Hasil penelitiannya menyimpulkan bahwa bahasa Saluan tidak memiliki ciri secara khusus dalam variasi fonologi, variasi leksikal dalam bahasa Saluan tersebar dalam satu kecamatan, dua kecamatan, dan seluruh kecamatan secara acak, selain itu, hasil penelitian Pamolango disebutkan bahwa hanya terjadi perbedaan wicara dalam tempat penelitiannya.

Afria (2017;2019), secara terpisah meneliti tentang variasi fonologis dan variasi leksikal di Kecamatan Bukitkerman, Kerinci. Hasil penelitiannya adalah terdapat variasi fonologis dan leksikal pada daerah yang ditelitinya. Berdasarkan hasil analisis sinkronis, ditemukan variasi-variasi bunyi, yakni $[a],[a],[i],[u],[e],[\partial],[O],[O]]$, $[a w],[e w],[i y],[p],[b],[t],[k],[g],[m]$, 
Rengki Afria dan Mailani Muadzimah: Variasi Fonologi dan Leksikal Dialek Merangin...

$[n],[\eta],[n],[s],[d],[h],[?]$, dan [I] dalam beberapa posisi. Berdasarkan hasil analisis diakronis ditemukan fonem PIBK dari hasil proses rekonstruksi protobahasa pada posisi tertentu. Fonem tersebut berupa enam fonem vokal dua gugus bunyi, yaitu vokal $*|i|, *|u|, *|e|, *|\partial|, * / 0 /$ dengan luncuran gugus bunyi $\mid O P /$, dan $* / a \mid$ dengan meluncurkan gugus bunyi $|a\rangle \mid$; tujuh diftong *|aw|, *|ow|, *|ew|, *|iw|, */uw| dan $*|i y|, * / \partial y \mid$ dan sembilan belas fonem konsonan $*|p|, *|b|, *|t|, *|k|, *|g|, * / m /$, $*|n|, *|\eta|, *|n|, *|s|, *|d|, *|h|, *|\lambda|, * \mid l$, $*|r|, *|j|, *|c l, *| w \mid$, dan $* / y \mid$. Inovasi fonologis yang ditemukan berdasarkan kaidah perubahan bunyi, seperti: 1) metatesis; 2) afaresis; 3) pemecahan vokal; 4) apokop; dan 5) sinkop. Situasi kebasaan dari data penelitian disimpulkan tidak ada perbedaan. Variasi leksikal yang ditemukan dengan menggunakan Data bersumber dari 15 konsep data yang berjumlah 734 glos. Berdasarkan hasil analisis didapatkan 143 variasi, yakni: Bilangan dan Ukuran (1 glos); Waktu dan Musim (5 glos); Bagian Tubuh Manusia (13 glos); Kata Ganti dan Istilah Kekerabatan (12 glos); Pakaian dan Perhiasan (4 glos); Jabatan dan Pekerjaan (4 glos); Binatang (13 glos); Tumbuhan (17 glos); Alam (12 glos); Bau dan Rasa (2 glos); Sifat, keadaan dan warna (13 glos); Rumah (9 glos); Alat (8 glos); Kehidupan masyarakat (4 glos); Makanan dan minuman (1 glos); Penyakit dan obat (2 glos); Aktivitas (20 glos); Nama Hari (0 glos); Glos tanya (2 glos); Kesenian dan permainan (1 glos). Sedangkan jarak kosakata dari tiga TP tersebut adalah IPp - IP 4\%, IP - IM 5,5\%, dan IM - Ipp 6\% dengan keterangan tidak ada perbedaan. Relevansinya terhadap penelitian ini adalah teori dan metode yang digunakan, tetapi berbeda pada objek kajian bahasa/dialek.

Selanjutnya, Antono, et,al (2019) berjudul pemertahanan leksikal dan fonologis dalam bahasa Jawa di Kabupaten Wonogiri dengan kajian geografi dialek. Penelitian tersebut menggunakan penelitian deskriptif kualitatif dan membahas mengenai deskripsi tentang pemertahanan fonologi dan leksikal dalam bahasa Jawa, teknik yang digunakan dalam penelitian tersebut adalah simak dan cakap. Hasil penelitiannya adalah adanya pemertahanan fonem (vokal dan konsonan) dan pemertahanan leksikal yang disebabkan oleh faktor geografis, faktor budaya, dan penutur (dalam bahasa Jawa). Relevansi penelitian tersebut dengan penelitian ini juga terletak pada teori dan metode. Penelitian tersebut menghasilkan output berpa peta bahasa, sedangkan penelitian ini mendeskripsikan perbedaan bahasa/dialek dalam bentuk persentase dialektometri.

Penelitian mengenai variasi fonologi dan leksikal juga dilakukan oleh Harahap (2014) meneliti tentang variasi fonologi dan leksikon dialek Angkola di Kabupaten Tapanuli Selatan. Tujuan penelitiannya adalah untuk mendeskripsikan variasi fonologi dan leksokon dalam dialek Angkola, data yang ia peroleh disusun sesuai kata kerja, kata sifat, dan kata benda. Temuannya adalah adanya perbedaan secara fonologi dalam dialek Angkola dan faktor geografis yang memengaruhi variasi.

Ketiga penelitian terdahulu yang telah dipaparkan dapat disimpulkan bahwa penelitian tersebut relevan dengan penelitian ini dalam hal teori dan metode, sedangkan perbedaannya adalah terletak pada substansi hasil penelitian, mengingat objek bahasa/dialek kajian sudah berbeda. Berdasarkan observasi lapangan, kajian ini belum pernah dilakukan di DP, baik dalam bentuk skripsi, jurnal, maupun artikel ilmiah lainnya, sehingga hasilnya nanti juga merupakan temuan terbaru dalam bidang dialektologi.

\section{METODE PENELITIAN}

Metode penelitian yang digunakan dalam penelitian ini adalah metode deskriptif (Moleong, 2012) kuantitatif kualitatif, yakni mendeskripsikan dan memaparkan variasi dialek secara fonologi dan leksikal, serta menggunakan cara penerjemahan dalam bentuk transkripsi dan penghitungan data (Mahsun, 2012). Adapun alasan mengapa mengambil metode ini karena belum ada penelitian yang dilakukan, sehingga belum ada data pengelompokkannya. Adapun sumber data penelitian ini adalah penutur yang berasal dari Kabupaten Merangin, Kecamatan Pangkalanjambu: Desa Bungotanjung, Kampunglimo, dan Sungaijering. Pengambilan data menggunakan teknik cakap, simak, rekam suara telepon, dan catat. 
Rengki Afria dan Mailani Muadzimah: Variasi Fonologi dan Leksikal Dialek Merangin...

Data berupa 200 kosakata yang bersumber dari Swadesh. Analisis data menggunakan metode dialektometri untuk menghitung persentase perbedaan. Pemilihan informan sesuai dengan syaratsyarat yang telah ditentukan, yakni informan adalah orang yang benar-benar tinggal di daerah penelitian, berusia 20-60 tahun yang fasih menggunakan bahasa atau dialek daerahnya.

Dialektometri merupakan rumus yang digunakan untuk mengetahui seberapa jauh atau seberapa banyak perbedaan dialek di tempat yang diteliti tersebut, dan membandingkan data yang terkumpul dari tempat penelitian tersebut (Mahsun, 1995; Nadra \& Reniwati, 2009).

$\frac{s \times 100}{n}=\mathbf{d} \%$

$\mathrm{S}=$ Jumlah beda dengan titik pengamatan

$\mathrm{n}=$ Jumlah peta yang dibandingkan

$\mathrm{d}=$ Persentase jarak dialek antartitik pengamatan

Lalu, persentase untuk menentukan hubungan antartitik pengamatan dengan kriteria, yakni:

Tabel 1

Persentase dan status kebahasaaan fonologi dan leksikal

\begin{tabular}{llll}
\hline \multicolumn{2}{l}{ Persentase perbedaan fonologi } & \multicolumn{2}{l}{ Persentase perbedaan leksikal } \\
\hline $17 \%>$ & $=$ perbedaan bahasa & $>81 \%$ & $=$ perbedaan bahasa \\
$12 \%-16 \%$ & $=$ perbedaan dialek & $51 \%-80 \%$ & $=$ perbedaan dialek \\
$8 \%-11 \%$ & $=$ perbedaan subdialek & $31 \%-50 \%$ & $=$ perbedaan subdialek \\
$4 \%-7 \%$ & $=$ perbedaan wicara & $21 \%-30 \%$ & $=$ perbedaan wicara \\
$0 \%-3 \%$ & $=$ tidak ada perbedan & $<20 \%$ & $=$ tidak ada perbedaan \\
\hline
\end{tabular}

Sumber: Mahsun, 1995; Chambers \& Trudgill, 2004; Fernandez, 1993)

\section{HASIL DAN PEMBAHASAN}

\subsection{Variasi Fonologi}

\subsubsection{Variasi Vokal}

1) Variasi a $\sim a \sim \varnothing /$ penultima

Variasi /a/ muncul pada satu korespondensi, yakni a $\sim a \sim \varnothing$ pada posisi penultima. Bunyi [a] muncul pada TP1 dan TP2, dan bunyi [Ø] muncul pada TP3 di data 139.

139 matahari matahaRi matohaRi matoRi

\section{2) Variasi ə a $\sim \varnothing /$ antepenultima}

Variasi /a/ muncul pada korespondensi $ə \sim a$ $\sim \varnothing$ pada posisi antepenultima. Bunyi [ə] muncul pada TP1, bunyi [a] muncul pada TP2, bunyi [Ø] muncul pada TP3 di data 156.

156 perempuan bətinO batinO tinO

\section{3) Variasi a $\sim \varnothing \sim \varnothing / \#-$}

Variasi [a] muncul pada korespondensi a $\sim \varnothing$ $\sim \varnothing$ pada posisi awal. Bunyi [a] muncul pada TP1, bunyi $[\varnothing]$ muncul pada TP2 dan TP3 di data 172.

172 semua lagalO galO-galO galO

\section{4) Variasi $\emptyset \sim a \sim \varnothing / a n t e p e n u l t i m a$} Variasi /a/ muncul pada korespondensi $\varnothing \sim$ a $\sim \varnothing$ pada posisi antepenultima. Bunyi [ $\varnothing]$ muncul pada TP1 dan TP3, bunyi [a] muncul pada TP2 di data 184.
184 telinga linO? talinO? linO?

5) Variasi a $0 \sim 0 /$ penultima Variasi /a/ muncul pada satu korespondensi, yakni a o o pada posisi penultima. Bunyi [a] muncul pada TP1, dan bunyi [o] muncul pada TP2 dan TP3 di data 139.

139 matahari matahaRi matohaRi matoRi

\section{6) Variasi $\varepsilon \sim a$ a/antepenultima dan ultima}

Variasi /a/ muncul pada satu korespondesi, yakni $\varepsilon \sim a \sim a$ pada posisi antepenultima . Bunyi $[\varepsilon]$ muncul pada TP1, dan bunyi [a] muncul pada TP2 dan Tp3 di data 30.

30 berjalan jalen/pai bəjalan jalan

\section{7) Variasi a $\sim a \sim \varepsilon /$ ultima}

Variasi /r/ muncul pada korespondensi a a $\varepsilon$ dengan posisi ultima. Bunyi [a] muncul pada TP1 dan TP2, bunyi $[\varepsilon]$ muncul pada TP3 di data 162.

162 pusar pusaR pusaR puse?

8) Variasi a $\sim \mathbf{a} \sim 0 / \#-, \mathbf{a} \sim \mathbf{a} \sim$ o/penultima dan a $\sim a \sim 0 /-\#$

Variasi /a/ muncul pada satu korespondensi, yakni a a o pada posisi awal. Bunyi [a] muncul pada TP1 dan TP2, dan bunyi [0] 
Rengki Afria dan Mailani Muadzimah: Variasi Fonologi dan Leksikal Dialek Merangin...

muncul pada TP3 di data 80 dengan posisi awal.

80 hantam hantam hantam Ontam

34 bilamana bilamana bilamana bilOmano

\section{9) Variasi o a o/penultima}

Variasi /a/ muncul pada satu korespondensi, yakni o a o pada posisi penultima. Bunyi [0] muncul pada TP1 dan TP3, dan bunyi [a] muncul pada TP2 di data 109.

109 Karena karnO karena karno

\section{0) Variasi a o a/penultima}

Variasi /a/ muncul pada korespondensi, yakni a $\sim 0 \sim$ a pada posisi penultima. Bunyi [a] muncul pada TP1 dan TP3, bunyi [0] muncul pada TP2 di data 105.

105 kalau Kalau kalou kalau

\section{1) Variasi i a a/-\#}

Variasi /a/ muncul pada satu korespondensi, yakni i $\sim$ a $\sim$ a pada posisi akhir. Bunyi [i] muncul pada TP1, dan bunyi [a] muncul pada TP2 dan TP3 di data 181 sebagai posisi akhir.

181 Tangan tanin tanan tanan

\section{2) Variasi a i a/ \#-}

Variasi /a/ muncul pada satu korespondensi, yakni a $\sim$ i $\sim$ a pada posisi awal. Bunyi [a] muncul pada TP1 dan TP3, bunyi [i] muncul pada TP2 di data 46. Perhatikan tabel berikut!

46 Cacing cacin cipcin cacin

\section{3) Variasi o a a/penultima}

Variasi /a/ muncul pada dua korespondensi, yakni o a a pada posisi ultima. Bunyi [o] muncul pada TP1, bunyi [a] muncul pada TP2 dan TP3 di data 59 dan di data 137.

59 di dalam dalOm di dalam di dalam 137 malam malOm malam malam

\section{4) Variasi $\boldsymbol{i} \sim \boldsymbol{\varepsilon} \sim \mathbf{i} /-\#$}

Variasi [i] muncul pada korespondensi $\dot{i} \sim \varepsilon \sim$ i pada posisi akhir. Bunyi [i] muncul pada TP1, bunyi $[\varepsilon]$ muncul pada TP2, dan bunyi [i] muncul pada TP3 di data 158.

158 Pikir piki pike miki

\section{5) Variasi i $\sim \varnothing \sim \varnothing /$ ultima}

Variasi /i/ muncul pada korespondensi i $\sim \varnothing \sim$ $\varnothing$ dengan posisi ultima. Bunyi [i] muncul pada TP1, bunyi [Ø] muncul pada TP2 dan TP3 di data 189.
189 Tidak ida? da? da?

\section{6) Variasi i i ø/ultima}

Variasi /i/ muncul pada satu korespondensi, yakni i $\sim$ i $\sim \varnothing$ pada posisi ultima. Bunyi [i] muncul pada TP1 dan TP2, dan bunyi [ muncul pada TP3 di data 97.

97 Itu itu itu tu

\section{7) Variasi i $\sim \varepsilon \sim i /$ ultima dan penultima}

Variasi /i/ muncul pada korespondensi yakni $\mathrm{i} \sim \varepsilon \sim \mathrm{i}$, pada posisi ultima dan penultima. Bunyi [i] muncul pada TP1 dan TP3, bunyi [ع] muncul pada TP2 di data 7 dan data 119.

$\begin{array}{llll}7 & \text { Angin anin anen anin } \\ 119 & \text { kuning kunin kunen kunin }\end{array}$

\section{8) Variasi $\varepsilon \sim \varepsilon \sim i /$ ultima}

Variasi /i/ muncul pada korespondensi $\varepsilon \sim \varepsilon \sim$ i pada posisi ultima. Bunyi $[\varepsilon]$ muncul pada TP1 dan TP2, bunyi [i] muncul pada TP3 di data 121.

121 Lain lacn lain lain

\section{9) Variasi $u$ i i//ultima}

Variasi /u/ muncul pada satu korespondensi, yakni u $\sim$ i i pada posisi ultima. Bunyi [u] muncul pada TP1, dan bunyi [i] muncul pada TP2 dan TP3 di data 76.

76 Gigi gugu gigi gigi

\section{0) Variasi o u u/-\# dan ultima} Variasi /u/ muncul pada korespondensi, yakni o $\sim \mathrm{u} \sim \mathrm{u}$ pada posisi akhir dan ultima. Bunyi [o] muncul pada TP1, bunyi [u] muncul pada TP2 dan TP3 di data 41, data 190, dan data 185.

$\begin{array}{llccc}41 & \text { Bunuh } & \text { bunOh } & \text { bunuh } & \text { bunuh } \\ 190 & \text { Tidur } & \text { tidO } & \text { tidu } & \text { tidu } \\ 185 & \text { Telur } & \text { talO } & \text { tOlu } & \text { tOlu }\end{array}$

21) Variasi $0 \sim u \sim 0 /-\#$

Variasi /u/ muncul pada korespondensi, yakni o $\sim$ u $\sim$ o pada posisi akhir. Bunyi [o] muncul pada TP1 dan TP3, bunyi [u] muncul pada TP2 di data 116.

116 Kotor kumOh kumuh kumOh

\section{2) Variasi u $\sim 0 \sim$ u/penultima}

Variasi /u/ muncul pada korespondensi u $\sim 0$ $\sim \mathrm{u}$ pada posisi penultima. Bunyi [u] muncul pada TP1 dan TP3, bunyi [o] muncul pada TP2 di data 143.

143 minum minun minOm minum 
23) Variasi $\varepsilon \sim \mathbf{i} \sim \mathbf{i} /-\#$

Variasi /i/ muncul pada satu korespondensi, yakni $\varepsilon \sim$ i i pada posisi akhir. Bunyi $/ \varepsilon /$ muncul pada TP1, bunyi /i/ muncul pada TP2 dan TP3 di data 182.

182 Tarik taRe? taRi? taRi?

\section{4) Variasi i $\sim \mathbf{i} \sim \varepsilon$ /\#-}

Variasi /i/ muncul pada satu korespondensi, yakni i $\sim$ i $\sim \varepsilon$ pada posisi awal. Bunyi [i] muncul pada TP1 dan TP2, dan bunyi $[\varepsilon]$ muncul pada TP3 di data 69.

69 Ekor iku? iku? हkor

\section{5) Variasi $\mathbf{i} \sim \varepsilon \quad \sim \mathbf{i}-\#$}

Variasi /i/ muncul pada satu korespondensi, yakni i $\sim \varepsilon \sim$ i pada posisi akhir. Bunyi [i] muncul pada TP1 dan TP3, bunyi $[\varepsilon]$ muncul pada Tp2 di data 62.

62 Dingin dinin dinen dinin

\section{6) Variasi $\varnothing \sim \partial \sim \varnothing /$-\#}

Variasi /e/ muncul pada satu korespondesi, yakni $\varnothing \sim \partial \sim \varnothing$ pada posisi awal. Bunyi [Ø] muncul pada TP1 dan Tp3, dan bunyi [ə] muncul pada TP2 di data 30 sebagai posisi awal.

30 Berjalan jalen/pai bəjalan jalan

\section{7) Variasi ə a ə /\#-}

Variasi/e/ muncul pada satu korespondensi, yakni $ə \sim a \sim \partial$ pada posisi awal. Bunyi [ə] muncul pada TP1 dan TP3. dan [a] muncul pada TP2 di data 55.

55 Debu debu abu debu

\section{8) Variasi ə ə 0/ penultima}

Variasi /e/ muncul pada korespondensi, yakni $\partial \sim \partial \sim 0$ pada posisi penultima. Bunyi [ə] muncul pada TP1 dan TP2, bunyi [o] muncul pada TP3 di data 33, 153, 157, dan 187.

$\begin{array}{clccc}33 & \text { Besar } & \text { gədan } & \text { gədan } & \text { gOdan } \\ 153 & \text { Pegang } & \text { pəgan } & \text { pəgan } & \text { pOgan } \\ 157 & \text { Perut } & \text { pəRui? } & \text { pəRut } & \text { pORuit } \\ 187 & \text { Tertawa } & \text { gəla? } & \text { gəla? } & \text { gOla? }\end{array}$

\section{9) Variasi $\emptyset \sim ə \sim 0 / p e n u l t i m a$}

Variasi /e/ muncul pada korespondensi $\varnothing \sim \partial$ o dengan posisi penultima. Bunyi [ $\varnothing]$ muncul pada TP1, bunyi [ə] muncul pada TP2, bunyi [o] muncul pada TP3 di data 187.

\section{0) Variasi $\varnothing \sim \curvearrowright \sim \varnothing /$ penultima dan -\#}

Variasi /e/ muncul pada dua korespondensi, yakni $\varnothing \sim \partial \sim \varnothing$ pada posisi penultima. Bunyi [Ø] muncul pada TP1 dan TP3, dan bunyi [ə] muncul pada TP2 di data 109 dan data 113.

$\begin{array}{lllcl}109 & \text { Karena karnO karəna karnO } \\ 113 & \text { Kepala } & \text { palO? kəpalO? } & \text { palO? }\end{array}$

31) Variasi ə $\sim 0 \sim 0 /$ ultima dan \#-

Variasi /e/ muncul pada tiga korespondensi, yakni ə 0 o pada posisi ultima dan awal. Bunyi [ə] muncul pada TP1, dan bunyi [0] muncul pada TP2 dan TP3 di data 58, 94, $114,152,70,171,28,183,185$ dan data 186.

\begin{tabular}{|c|c|c|c|c|}
\hline 94 & Ikat & kəbə? & kObe? & kObe? \\
\hline 114 & Kering & kəRin & kORin & kORin \\
\hline 152 & Pasir & kəsi? & kOsi? & kOsi? \\
\hline 70 & Empat & әmp\&? & Ompe? & Ompe? \\
\hline 28 & Bengkak & 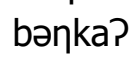 & bəクka? & bOnka? \\
\hline 58 & Dengar & dəпa & dOna & dOna \\
\hline 171 & Sempit & səmpi? & sOmpi? & sOmpi? \\
\hline 183 & Tebal & thho & tOba & tOba \\
\hline 185 & Telur & təlO & tOlu & tOlu \\
\hline 186 & Terbang & təban & tOban & tOban \\
\hline
\end{tabular}

\section{2) Variasi ə $\sim 0 \sim$ o/penultima}

Variasi /e/ muncul pada satu korespondensi, yakni $ə \sim 0 \sim \partial$ pada posisi penultima. Bunyi [ə] muncul pada TP1 dan TP3, bunyi [0] muncul pada TP2 di data 29.

29 Berenang bənan baronan bərənan

\section{3) Variasi $\emptyset \sim \ni \sim 0 / \#-$}

Variasi /e/ muncul pada korespondensi $\varnothing \sim \partial$ $\sim$ o dengan posisi awal. Bunyi [ $\varnothing]$ muncul pada TP1, bunyi [ə] muncul pada TP2, dan bunyi [0] muncul pada TP3 di data 194 .

194 Tiup mbuih əmbus Ombuih

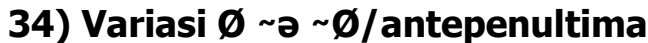

Variasi /e/ muncul pada korespondensi $\varnothing \sim$ $\sim \varnothing$ dengan posisi antepenultima. Bunyi $[\varnothing]$ muncul pada TP1 dan TP3, bunyi [ə] muncul pada TP2 di data168.

168 Sedikit dikI? sədikI? dikI?

\section{5) Variasi $\varnothing \sim 0 \sim$ \% penultima}

Variasi /e/ muncul pada satu korespondensi, yakni $\varnothing \sim 0 \sim$ p pada posisi penultima. Bunyi [Ø] muncul pada TP1, bunyi [o] muncul pada TP2, dan bunyi [ə] muncul pada TP3 di data 29. 
Rengki Afria dan Mailani Muadzimah: Variasi Fonologi dan Leksikal Dialek Merangin...

29 Berenang bənan baronan bərənan

36) Variasi u a a/-\# dan \#-

Variasi /u/ muncul pada satu korespondensi, yakni u $\sim$ a $\sim$ a pada posisi akhir dan awal. Bunyi [u] muncul pada TP1, dan bunyi [a] muncul pada TP2 dan TP3 di data 115.

151 Panjang panjun panjan panjan

\section{7) Variasi u $\sim 0 \sim$ u/penultima}

Variasi /o/ muncul pada satu korespondensi, yakni u o u pada posisi penultima. Bunyi [u] muncul pada TP1 dan TP3, dan bunyi [0] muncul pada TP2 di data 79 dan data 149 ..

$\begin{array}{clll}79 & \text { Gunung } & \text { gunon gunun gunun } \\ 149 & \text { Orang } & \text { oRan uRan uRan }\end{array}$

38) Variasi o $\sim \mathrm{u} \sim \mathrm{u} /$

Variasi /o/ muncul pada korespondensi o u $\sim$ u dengan posisi awal. Bunyi [o] muncul pada TP1, bunyi [u] muncul TP2 dan TP3 di.

\section{9) Variasi $\varnothing \sim 0 \sim 0 /$ ultima}

Variasi /o/ muncul pada satu korespondensi, yakni $\varnothing \sim 0 \sim 0$ pada posisi ultima. Bunyi [ $\varnothing]$ muncul pada TP1, bunyi \{0] muncul pada TP2 dan TP3 di data 31.

31 Berat bRe? boRk? boRk?

\subsubsection{Variasi Konsonan}

40) Variasi $\varnothing \sim b \sim \varnothing /$-\#

Variasi /b/ muncul pada satu korespondesi, yakni $\varnothing \sim \mathrm{b} \sim \varnothing$ pada posisi awal. Bunyi [ $\varnothing]$ muncul pada TP1 dan Tp3, dan bunyi [b] muncul pada TP2 di data 30 sebagai posisi awal.

30 Berjalan jalkn/pai bəjalan jalan

\section{1) Variasi $b \sim \mathbf{b} \sim \varnothing /$ antepenultima}

Variasi /b/ muncul pada korespondensi $b \sim b$

$\sim \varnothing$ pada posisi antepenultima. Bunyi [b] muncul pada TP1 dan TP2, bunyi [ $\varnothing]$ muncul pada TP3 di data 156.

156 Perempuan bətinO batinO tinO

\section{2) Variasi $\mathbf{g} \sim \mathbf{g} \sim \mathbf{\eta} /$-\#}

Variasi $/ \mathrm{g} /$ muncul pada satu korespondensi, yakni $\mathrm{g} \sim \mathrm{g} \sim \eta$ pada posisi akhir. Bunyi [g] mncul pada TP1 dan TP2, bunyi [n] muncul pada TP3 di data 78.

78 Gosok goso? goso? noso?

\section{3) Variasi $g \sim \eta \sim g$ / ultima}

Variasi / $\mathrm{g} /$ muncul pada korespondensi $\mathrm{g} \sim \eta$ g pada posisi ultima. Bunyi [g] muncul pada TP1 dan TP3, bunyi [n] muncu pada TP2 di data 72.

72 Gali gali nali? galih

44) Variasi $h \sim \emptyset \sim \emptyset / \#-$

Variasi /h/ muncul pada dua korespondensi, yakni $\mathrm{h} \sim \varnothing \sim \varnothing$ pada posisi awal. Bunyi [h] muncul pada TP1, dan bunyi [Ø] muncul pada TP2 di data 81, 85 dan 89.

$\begin{array}{llcc}81 & \text { Hapus hapuih apus apuih } \\ 85 & \text { Hijau hijau Ijau ijow } \\ 89 & \text { Hujan hujan ujan ujan }\end{array}$

45) Variasi $\mathbf{h} \sim \mathbf{h} \sim \varnothing /$ /- dan penultima Variasi /h/ muncul pada satu korespondensi, yakni $h \sim h \sim \varnothing$ pada posisi awal. Bunyi [h] muncul pada TP1 dan TP2, dan bunyi [ $\varnothing]$ muncul pada TP3 di data 80 dengan posisi awal dan data 139 pada posisi penultima.

80 hantam hantam hantam Ontam 139 Matahari matahaRi matohaRi matoRi

\section{6) Variasi $\emptyset \sim p \sim h$ /ultima}

Variasi / $\mathrm{h} /$ terjadi pada korespondensi, yakni $\varnothing \sim ? \sim \mathrm{h}$ di posisi ultima. Bunyi [ $\varnothing]$ muncul pada TP1, bunyi [?] muncul pada TP2, dan bunyi [h] muncul pada TP3 di data 72.

72 Gali gali nali? galih

\section{7) Variasi $\emptyset \sim \emptyset \sim$ h/ultima}

Variasi /h/ muncul pada korespondensi, yakni $\varnothing \sim \varnothing \sim$ h pada posisi ultima. Bunyi [ $\varnothing]$ muncul pada TP1 dan TP2, bunyi [h] muncul pada TP3 di data 82.

82 Hati ati ati hati

\section{8) Variasi $\emptyset h \sim \varnothing / \#-$}

Variasi /h/ muncul pada korespondensi, yakni $\varnothing \quad h \sim \varnothing$ pada posisi awal. Bunyi [ $\varnothing]$ muncul pada TP1 dan TP3, bunyi [h] muncul pada TP2 di data 84.

84 Hidup idui? hidui? idui?

49) Variasi $h \sim \emptyset \sim h /$ penultima

Variasi / $h$ / muncul pada korespondensi $h \sim \varnothing$ $\sim \mathrm{h}$ pada poisisi penultima. Bunyi [h] muncul pada TP1 dan TP3, bunyi [Ø] muncul pada TP2 di data 177.

177 Tahun tahUn taUn tahUn 
Rengki Afria dan Mailani Muadzimah: Variasi Fonologi dan Leksikal Dialek Merangin...

50) Variasi $h \sim R \sim R /$ penultima

Variasi /h/ muncul pada korspondensi $h \sim R \sim$ $\mathrm{R}$ pada posisi penultima. Bunyi [h] muncul pada TP1, bunyi [R] muncul pada TP2 dan TP3 di data 160.

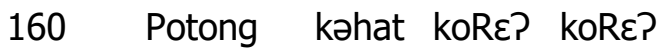

\section{1) Variasi $h \sim s \sim h /-\#$}

Variasi / $\mathrm{h} /$ muncul pada korespondensi $\mathrm{h} \sim \mathrm{S}$ $\sim \mathrm{h}$ dengan posisi awal. Bunyi [h] muncul pada TP1 dan TP3, dan bunyi [s] muncul pada TP2 di data 194.

194 Tiup mbuih əmbus Ombuih

52) Variasi $\varnothing \sim p \sim \varnothing$ / penultima

Variasi /k/ muncul pada satu korespondensi, yakni $\varnothing \sim ? \sim \varnothing$ pada posisi penultima. Bunyi [Ø] muncul pada TP1 dan TP3, bunyi [?] muncul pada TP2 di data 46. Perhatikan tabel berikut!

46 Cacing cacin cipcin cacin

53) Variasi $k \sim \eta \sim k$ /\#-

Variasi /k/ muncul pada korespondensi, yakni $k \sim \eta \sim k$ pada posisi awal. Bunyi [k] muncul pada TP1 dan TP3, bunyi [n] muncul pada TP2 di data 91.

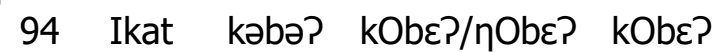

\section{4) Variasi I $\sim \varnothing \sim \varnothing / \#-$}

Variasi [I] muncul pada korespondensi I $\varnothing \sim \varnothing$ pada posisi awal. Bunyi [I] muncul pada TP1, bunyi $[\varnothing]$ muncul pada TP2 dan TP3 di data 172.

172 Semua lagalO galO-galO galO

55) Variasi $\mathbf{n} \sim \mathbf{m} \sim \mathbf{m} /$-\#

Variasi /m/ muncul pada korespondensi $\mathrm{n}$ $\mathrm{m} \sim \mathrm{m}$ pada posisi -\#. Bunyi [n] muncul pada TP1 dan TP3, bunyi [m] muncul pada TP2 di data 143.

143 minum minun minOm minum

56) Variasi $P \sim t \sim P /-\#$

Variasi /k/ muncul pada korespondensi, yakni $? \sim \mathrm{t} \sim$ ? pada posisi -\#. Bunyi [?] muncul pada TP1 dan TP3, bunyi [t] muncul pada TP2 di data 98.

98 Jahit jai? jait jai?

57) Variasi $p \sim p \sim m / \#-$

Variasi [p] muncul pada korespondensi $p \sim p$ $\sim$ m pada posisi awal. Bunyi [p] muncul pada TP1dan TP2, bunyi [m] muncul pada TP3 di data 158.
158 Pikir piki pike miki

\section{8) Variasi $R \sim \emptyset \sim R / \#-$}

Variasi / $r$ / muncul pada korespondensi $R \sim \varnothing$ $\sim R$ pada posisi awal. Bunyi [R] muncul pada TP1 dan TP3, bunyi [Ø] muncul pada TP2 di data 164 dan data 165 .

164 rambut rambui? ambui? rambui?

\section{9) Variasi $\mathbf{R} \sim \varnothing \sim \varnothing / \#-$ dan -\#}

Variasi / $\mathrm{r} /$ muncul pada korespondensi $\mathrm{R} \sim \varnothing$

$\sim \varnothing$ pada posisi awal dan akhir. Bunyi [R] muncul pada TP1, bunyi $[\varnothing]$ muncul pada TP2 dan TP3 di data 165 dan data 3.

165 rumput Rumput umpui? umpui?

3 Akar akaR aka aka

\section{0) Variasi $\varnothing \sim r \sim r /$ penultima}

Variasi /e/ muncul pada satu korespondensi, yakni $\varnothing \sim r \sim r$ pada posisi penultima. Bunyi [Ø] muncul pada TP1, bunyi [r] muncul pada TP2 dan TP3 di data 29.

29 Berenang bənan baronan bərənan

\section{1) Variasi $\mathbf{R} \sim \mathbf{R} \sim \emptyset$}

Variasi / $r /$ muncul pada satu korespondensi, yakni $R \sim R \sim \varnothing$ pada posisi ultima. Bunyi $[R]$ muncul pada TP1 dan TP2, dan bunyi [ie] muncul pada TP3 di data 5 .

5 alir (me) aliR aliR alie

\section{2) Variasi $P \sim P \sim r /-\#$}

Variasi / $r$ / muncul pada satu korespondensi, yakni ? $\sim$ ? r pada posisi akhir. Bunyi [?] muncul pada TP1 dan TP2, dan bunyi [r] muncul pada TP3 di data 69.

69 Ekor iku? iku? $\varepsilon k o r$

\section{3) Variasi $R \sim R \sim P /$ ultima}

Variasi / $r$ / muncul pada korespondensi $R \sim R$

$\sim$ dengan posisi ultima. Bunyi $[R]$ muncul pada TP1 dan TP2, bunyi [?] muncul pada TP3 di data 162.

162 Pusar pusaR pusaR puse?

\section{4) Variasi $h \sim s \sim h /-\#$}

Variasi /s/ muncul pada satu korespondensi, yakni $\mathrm{h} \sim \mathrm{s} \sim \mathrm{h}$ pada posisi akhir. Bunyi [h] muncul pada TP1 dan Tp3, dan bunyi [s] muncul pada TP2 di data 81 .

81 Hapus hapuih apus apuih

\section{5) Variasi $\varnothing \sim s \sim \varnothing / a n t e p e n u l t i m a$}

Variasi /s/ muncul pada korespondensi $\varnothing \sim \mathrm{s}$ $\sim \varnothing$ dengan posisi antepenultima. Bunyi [ $\varnothing]$ 
Rengki Afria dan Mailani Muadzimah: Variasi Fonologi dan Leksikal Dialek Merangin...

muncul pada TP1 dan TP3, bunyi [s] muncul pada TP2 di data168.

168 sedikit dikI? sədikI? dikI?

\section{6) Variasi $\varnothing \sim \mathrm{t} \sim \varnothing /$ antepenultima}

Variasi /t/ muncul pada korespondensi $\varnothing \sim \mathrm{t}$ $\sim \varnothing$ pada posisi antepenultima. Bunyi [Ø] muncul pada TP1 dan TP3, bunyi [t] muncul pada TP2 di data 184.

184 telinga linO? talinO? linO?

\section{7) Variasi $t \sim P \sim P /-\#$}

Variasi /t/ muncul pada korespondensi $t \sim$ ? $\sim$ ? pada posisi -\#. Bunyi [t] muncul pada TP1, bunyi [P] muncul pada TP2 dan TP3 di data 123 dan data 160 .

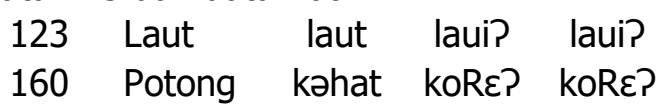

\section{8) Variasi $P \sim t \sim t /-\#$}

Variasi /t/ muncul pada satu korespondensi, yakni ? $\sim \mathrm{t} \sim \mathrm{t}$ pada posisi akhir. Bunyi [?] muncul pada TP1, dan bunyi [t] TP2 dan TP3 di data 157.

157 Perut pəRui? peRut poRuit

\section{9) Variasi y $\sim y \sim \varnothing /$ ultima}

Variasi /y/ muncul pada satu korespondensi, yakni y $\sim$ y $\sim \varnothing$ pada posisi ultima. Bunyi [y] muncul pada TP1 dan TP2, dan bunyi [ $\varnothing]$ muncul pada Tp3 di data 2.
2 Air
ayi?
ayi? aie

\section{0) Variasi $\emptyset \sim y \sim \varnothing /$ ultima}

Variasi /y/ muncul pada korespondensi $\varnothing \sim \mathrm{y}$ $\sim \varnothing$ pada posisi ultima. Bunyi [Ø] muncul pada TP1 dan TP3, bunyi /y/ muncul pada TP2 di data 166.

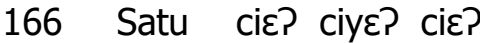

Berdasarkan pemaparan data di atas didapatkan 2 variasi pada TP1-TP2, 4 Variasi pada TP2-TP3, dan 5 Variasi pada TP3-TP1. Untuk menentukan status kebahasaan dari ketiga titik pengamatan tersebut, maka digunakan metode dialektomeri untuk menghitung persentase perbedaan dialek fonologi. Hal tersebut dijelaskan dalam rumus berikut.

TP1 dan TP2

$\frac{2 \times 100}{200}=\mathbf{1} \%$

TP2 dan TP3

$\frac{4 \times 100}{200}=2 \%$

TP3 dan TP1

$\frac{5 \times 100}{200}=2,5 \%$

Hasil dari perhitungan menggunakan rumus dialektometri di atas adalah variasi fonologi didapatkan 2 varian atau $1 \%$ pada TP1-TP2, 4 varian atau $2 \%$ pada TP2-TP3, dan 5 varian atau 2,5\% pada TP3-TP1. Artinya, hasil tersebut menunjukkan status kebahasaan tidak ada perbedaan.

Tabel 2

Persentase Variasi Fonologis dan Status Kebahasaan

\begin{tabular}{lcl}
\hline Titik Pengamatan & Jumlah Persentase & Status kebahasaan \\
\hline TP1 - TP2 & $1 \%$ & Tidak ada perbedaan \\
\hline TP2 - TP3 & $2 \%$ & Tidak ada perbedaan \\
\hline TP3 - TP1 & $2,5 \%$ & Tidak ada perbedaan \\
\hline
\end{tabular}

\subsection{Variasi Leksikal}

1) Pada glos yang bermakna 'saya' terdapat dua varian, yakni $a m b O$ dengan varian ambou di TP2, TP3 dan "aku"pada TP1.

2) Glos yang bermakna 'anak' direalisasikan dengan buyun pada TP1 dan anak pada TP2 dan TP3.

3) Glos yang bermakna 'benar' didapatkan bətu untuk TP1, dan bOna di TP2 dan TP3.
4) glos benih' direalisasikan dengan bOnch dengan varian bench pada TP2 dan TP3. Sementara TP1 menggunakan kata bibit.

5) Glos 'cuci' pada TP3 direalisasikan dengan basuh, sedangkan pda TP1 dan TP2 yakni nucibervarian dengan cuci.

6) Glos 'bau' pada TP2 didapatkan data busu?, sedangkan TP1 dan TP3 adalah baUn. 
Rengki Afria dan Mailani Muadzimah: Variasi Fonologi dan Leksikal Dialek Merangin...

7) Glos yang bermakna 'dorong' direalisasikan dengan tundO pada TP1, sedangkan TP2 dan TP3 menggunakan "tula?".

8) Glos makna 'kita' direalisasikan dengan mbou pada TP1, sedangkan TP2 dan TP3 menggunakan awa? dan wa?.

9) Glos makna 'kamu' pada TP1 direalisasikan dengan yo. Sedangkan TP2 dan TP3 direalisasikan dengan $U$ varian Uw.

10) Glos 'lempar' pada titik pengamaan ditemukan capa? pada TP2, sedangkan TP1 dan TP3 yang menggunakan bach.

11) Glos 'lihat' pada TP3 adalah coli? Sedangkan TP1 dan TP2 menggunakan kata $t \varepsilon \eta O P$ dan nEПO?.

12) Glos napas pada titik pengamatan ditemukan dua varian leksikal, yakni napeh di TP2 dan OnOP pada TP1 dan TP3.

13) Glos yang bermakna 'main' didapatkan dua varian leksikal, yakni busi? di TP3 dan maen pada TP1 dan TP2.

14) Glos yang bermakna 'berdiri' pada TP2 direalisasikan dengan bədiRi. Sedangkan TP1 dan TP3 menggunakan kata "toga?".

15) Glos 'hutan' direalisasikan dengan imbO pada TP1, sedangkan TP2 dan TP3 adalah utan.

16) Glos 'mati' di TP1 direalisasikan dengan bunuh. Sedangkan TP2 dan Tp3 adalah mati.

17) Glos 'mulut' di TP1 adalah muncun dan TP2-Tp3 adalah mului?.

18) Glos 'muntah' pada TP1 direalisasikan dengan mabur. Sedangkan TP2 dan TP3 adalah mutah dan muntah.

19) Glos yang bermakna 'pendek' pada TP3 direalisasikan dengan sinke?, sedangkan TP1 dan TP2 direalisasikan dengan panda? dan pende?

20) Potong, kehat TP1, koRe? TP2, dan \#

21) Glos 'punggung' direalisasikan dengan kudu? di TP1, sedangkan TP2 dan TP3, menggunakan kata pungun.

22) Glos 'tetek'direalisasikan dengan $t \varepsilon t \varepsilon ? d i$ TP2, sedangkan TP1 dan TP3, menggunakan kata $s U s U$.

23) Glos 'tikam' pada TP1 dan TP2 direalisasikan dengan nusu?, sedangkan TP3 adalah tankO?.
24) Glos 'tumpul' direalisasikan dengan tUmpU pada TP2. Sedangkan TP1 dan TP3 maja.

25) Glos berikut adalah perbedaan leksikal pada ketiga TP, baik TP1, TP2, dan TP3. Glos tersebut adalah 'baring', 'membelah', 'beri', 'gemuk', 'ia', 'ini', 'kelahi', 'lebar', 'merah', dan 'mereka'.

\begin{tabular}{|c|c|c|c|c|}
\hline 0 & Baring & baRin & 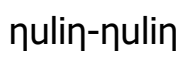 & talOntan \\
\hline & belah & $k R \varepsilon ?$ & bəlah & пOrE? \\
\hline & Beri & ambi? & baRi & bagih \\
\hline & Gemuk & Gədan & gəmu? & gəndut \\
\hline & Ia & an, mbou & diO & \\
\hline & Ini & Mbou & Iko/ko & \\
\hline 2 & Kelahi & cəka? & kəlahi & tir \\
\hline & Lebar & gədan & lebaR & \\
\hline & Merah & Sigah & mOnih & \\
\hline & Mereka & חv & uran tu & \\
\hline
\end{tabular}

Berdasarkan pemaparan data variasi leksikal di atas, digunakan metode dialektomeri untuk mengetahui persentase perbedaan dialek dari ketiga titik, yakni di Desa Bungotanjung, Desa Kampunglimo, dan Desa Sungaijering. Adapun persentase tersebut menggunakan rumus dialektometri adalah sebagai berikut:

TP1 dan TP2

$\frac{22 \times 100}{200}=\mathbf{1 1} \%$

TP2 dan TP3

$\frac{28 \times 100}{200}=\mathbf{1 4} \%$

TP3 dan TP1

$\frac{28 \times 100}{200}=14 \%$

Hasil dari perhitungan menggunakan rumus dialektometri di atas adalah variasi leksikal didapatkan 22 varian atau $11 \%$ pada TP1-TP2, 28 varian atau 14\% pada TP2-TP3, dan 28 varian atau $14 \%$ pada TP3-TP1. Artinya hasil tersebut menunjukkan status kebahasaan tidak ada perbedaan. 
Rengki Afria dan Mailani Muadzimah: Variasi Fonologi dan Leksikal Dialek Merangin...

Tabel 3

Persentase variasi leksikal dan status kebahasaan

\begin{tabular}{ccc}
\hline $\begin{array}{c}\text { Titik } \\
\text { Pengamatan }\end{array}$ & $\begin{array}{c}\text { Jumlah } \\
\text { Persentas }\end{array}$ & Status kebahasaan \\
\hline TP1 - TP2 & $1 \%$ & Tidak ada perbedaan \\
\hline TP2 - TP3 & $2 \%$ & Tidak ada perbedaan \\
\hline TP3 - TP1 & $2,5 \%$ & Tidak ada perbedaan \\
\hline
\end{tabular}

Dari analisis variasi fonologis dan leksikal melalui perhitungan persentase dialektometri didapatkan hasil status kebahasaannya adalah "tidak ada perbedaan". Hal tersebut disebabkan oleh beberapa faktor, seperti;
a. Faktor pertahanan identitas bahasa/dialek
b. Prestise pemakaian bahasa/dialek
c. Faktor kekeluargaan
d. Faktor budaya
e. Faktor sosial

\section{SIMPULAN}

Ada variasi fonologi dan leksikal dialek Merangin di desa Bungotanjung, Kampunglimo, dan Sungaijering Kecamatan Pangkalanjambu. Variasi tersebut berupa vokal dan konsonan. Hasil perbandingan titik pengamatan ditemukan variasi fonologi didapatkan 1\% (2 varian) pada TP1-TP2, $2 \%$ (4 varian) pada TP2-TP3, dan 2,5\% (5 varian) pada TP3-TP1. Sementara, variasi leksikal didapatkan 22 varian atau $11 \%$ pada TP1-TP2, 28 varian atau 14\% pada TP2-TP3, dan 28 varian atau 14\% pada TP3-TP1. Hasil variasi fonologi dan leksikal tersebut menunjukkan status kebahasaan tidak ada perbedaan. Status tersebut menunjukkan bahwa isolek Pangkalanjambu merupakan bagian dari bahasa Melayu, dialek Merangin. $\mathrm{Hal}$ tersebut dipengaruhi oleh faktor pertahanan identitas bahasa/dialek, prestise pemakaian bahasa/dialek, faktor kekeluargaan, faktor budaya dan faktor sosial.

\section{DAFTAR PUSTAKA}

Afria, R. (2017). VARIASI DAN

REKONSTRUKSI FONOLOGIS ISOLEK

KERINCI: STUDI DIALEKTOLOGI

DIAKRONIS DI KECAMATAN BUKIT

KERMAN. GENTA BAHTERA: Jurnal

Ilmiah Kebahasaan Dan Kesastraan,

3(1), 107-120.

https://doi.org/https://doi.org/10.26499

/gb.v3i1.9

Afria, R. (2019). VARIASI LEKSIKAL ISOLEK

TIGA DESA DI KECAMATAN

BUKITKERMAN KABUPATEN KERINCI :

KAJIAN DIALEKTOLOGI. GENTA

BAHTERA: Jurnal IImiah Kebahasaan

Dan Kesastraan, 5(2), 88-108.

https://doi.org/https://doi.org/10.26499

/gb.v5i2.73.g52

Antono, A., Zulaeha, I., \& Baehaqie, I. (2019). PEMERTAHANAN FONOLOGIS dan LEKSIKAL BAHASA JAWA di KABUPATEN WONOGIRI: KAJIAN GEOGRAFI DIALEK. JSI: Jurnal Sastra Indonesia, 8(1), 23-32.

https://journal.unnes.ac.id/sju/index.ph p/jsi/article/view/29854

Chambers, J. ., \& Trudgill, P. (2004). Dialectology: Second Edition. United Kingdom: Cambridge University Press.

Fernandez, I. Y. (1993). Dialektologi Sinkronis dan Diakronis: Sebuah Pengantar. Yogyakarta: Minat Utama Linguistik.

Harahap, E. M. (2014). VARIASI FONOLOGI DAN LEKSIKON DIALEK ANGKOLA DESA SIALAGUNDI DI DESA AEK GARUGUR KABUPATEN TAPANULI SELATAN. Metamorfosa Journal, 2(2), 31-52. https://metamorfosa.stkipgetsempena.a c.id/?journal $=$ home\&page $=$ article\&op $=v$ iew\&path\%5B\%5D=20\&path\%5B\%5D $=16$

Mahsun. (1995). Dialektologi Diakronis: Sebuah Pengantar. Yogyakarta: Gadjah Mada University Press.

Mahsun. (2012). Metode Penelitian Bahasa. Jakarta: Raja Grafindo Persada. 
Rengki Afria dan Mailani Muadzimah: Variasi Fonologi dan Leksikal Dialek Merangin...

Moleong, L. (2012). Metodologi Penelitian Kualitatif. Bandung: PT. Remaja Rosdakarya.

Nadra, \& Reniwati. (2009). Dialektologi; Teori dan Metode. Yogyakarta: Elmatera Publishing.

National Agency for the Development of Language and Books. (2020). Peta Bahasa.

https://petabahasa.kemdikbud.go.id/
Pamolango, V. A. (2012). Geografi dialek bahasa Saluan. PARAFRASE: Jurnal Kajian Kebahasaan \& Kesastraan, 12(02), 7-20. https://doi.org/https://doi.org/10.30996 /parafrase.v12i02.217 